\title{
HUBUNGAN REGULASI EMOSI DENGAN BULLYING PADA SISWA KELAS XII SMA NEGERI 2 MAKASSAR
}

\author{
Novadri Prasetio, Muh Daud, Andi Nasrawati Hamid \\ Fakultas Psikologi Universitas Negeri Makassar \\ E-mail: novadriprasetio10@gmail.com,daoed64@yahoo.com, Andi.nasrawati@unm.ac.id
}

\begin{abstract}
Bullying is a negative behavior that many students do. This behavior occurs a lot in the school environment carried out by senior students against juniors. The individual's ability to control emotions is low causing behavioral disturbances, so they choose to do bullying behavior. One of the factors that influence bullying behavior is emotion regulation. This study aims to determine the relationship between emotional regulation and bullying in class XII students at SMA Negeri 2 Makassar. Respondents in this study were 202 students using a simple random sampling technique. This study uses a quantitative approach with data analysis techniques Spearman rank correlation and t-test. The study used a bullying scale and an emotion regulation scale. The results showed there was a significant relationship between emotion regulation and bullying $(p=0.001, r=-0.230)$. Its means that the higher the emotional regulation, the lower the bullying in class XII students at SMA Negeri 2 Makassar and there are differences in bullying behavior based on gender. The implication of this research for students is that they need to improve their ability to regulate emotions to avoid bullying or other negative behavior.
\end{abstract}

Keywords: Emotion Regulation, Bullying, Students.

\begin{abstract}
ABSTRAK
Bullying merupakan perilaku negatif yang banyak dilakukan siswa. Perilaku ini banyak terjadi di lingkungan sekolah yang dilakukan oleh siswa senior terhadap junior. Kemampuan individu dalam mengontrol emosi yang rendah menyebabkan gangguan perilaku, sehingga memilih melakukan perilaku bullying. Salah satu faktor yang memengaruhi perilaku bullying yaitu regulasi emosi. Penelitian ini bertujuan untuk mengetahui hubungan regulasi emosi dengan bullying pada siswa kelas XII di SMA Negeri 2 Makassar. Responden dalam penelitian ini adalah 202 siswa dengan menggunakan teknik simple random sampling. Penelitian ini menggunakan pendekatan kuantitatif dengan teknik analisis data spearman rank correlation dan $t$-test. Penelitian menggunakan skala bullying dan skala regulasi emosi. Hasil penelitian menunjukkan bahwa ada hubungan yang signifikan antara regulasi emosi dengan bullying $(\mathrm{p}=0,001, r=-0,230)$. Artinya semakin tinggi regulasi emosi maka semakin rendah bullying pada siswa kelas XII di SMA Negeri 2 Makassar dan terdapat perbedaan perilaku bullying berdasarkan jenis kelamin. Implikasi penelitian ini bagi siswa yaitu perlu lebih meningkatkan kemampuan dalam meregulasi emosi sehingga terhindar dari perilaku bullying atau perilaku negatif lainnya.
\end{abstract}

Kata Kunci: Regulasi Emosi, Bullying, Siswa.

\section{PENDAHULUAN}

Perilaku negatif yang banyak dilakukan oleh siswa salah satunya adalah bullying, perilaku ini marak terjadi dilingkungan sekolah yang dilakukan oleh siswa senior terhadap junior. Maraknya 
kasus-kasus bullying yang dilakukan oleh siswa dalam lingkungan sekolah semakin banyak menghiasi deretan berita dihalaman media cetak maupun elektronik. Perilaku bullying yang ditemui tersebut tidak hanya dilakukan secara fisik namun juga secara psikologis. Perilaku bullying diartikan sebagai bentuk penindasan dan kekerasan yang dilakukandengan sengaja.

Perilaku bullying dilakukan oleh individu atau kelompok yang merasa lebih kuat kepada korban yang lebih lemah fisik ataupun mental secara berulang-ulang tanpa ada perlawanan dengan tujuan membuat korban menderita (Nicolaides, Toda, \& Smith, 2002). Kasus bullying yang kerap terjadi di sekolah setiap tahun kian memprihatinkan, adapun dalam kurun waktu 2011 hingga 2017 terdapat 26.000 kasus bullying yang terjadi di Indonesia. Setiap tahunnya kasus bullying terjadi dihampir semua sekolah di Indonesia. Kasus yang kerap terjadi disetiap sekolah adalah perilaku bullying verbal hingga kasus penindasan senior kepada junior terus bermunculan. Kasus bullying pernah terjadi di SMA Negeri 3 Setiabudi Jakarta Selatan pada tahun 2016 yang dilakukan oleh 6 orang siswa kelas XII terhadap beberapa siswa kelas $\mathrm{X}$ yang videonya viral di media sosial. Dalam aksinya para pelaku menjadikan kepala para korban sebagai asbak rokok dan ditumpahi minuman.
Tidak hanya itu, pelaku juga menyuruh korban merokok sambil mengenakan bra di luar baju seragam (https://makassar.terkini.id). Selain itu kasus bullying juga terjadi di SMA Negeri 1 Semarang yang mengakibatkan 2 orang siswa dikeluarkan dari sekolah. Kasus yang terjadi di SMA Negeri 1 Semarang ini membuat korbannya meninggal dunia (https://news.detik.com).

Berdasarkan hasil survei yang dilakukan sebelumnya, maka peneliti memfokuskan populasi penelitian pada siswa SMA Negeri 2 Makassar. Berdasarkan data tersebut maka peneliti melakukan studi awal sebagai sampel perilaku bullying di lingkungan sekolah. Studi awal dilakukan untuk mengukur kecenderungan perilaku bullying siswa kelas XII di SMA Negeri 2 Makassar pada 30 siswa, pengambilan data menggunakan skala mengenai bullying. Hasil studi awal diperoleh sebanyak 24 siswa (88\%) pernah melakukan bullying di sekolah dan 6 siswa (22\%) tidak pernah melakukan bullying dalam bentuk apapun. Bentuk bullying yang terjadi di SMA Negeri 2 Makassar berdasarkan hasil studi awal yaitu, sebanyak delapan siswa yang mengatakan pernah melakukan bullying berbentuk fisik, sebanyak sepuluh siswa yang mengatakan pernah melakukan bullying berbentuk verbal, dan sebanyak enam siswa yang 
mengatakan pernah melakukan bullying berbentuk relasional.

Berdasarkan hasil wawancara yang dilakukan peneliti terhadap guru bimbingan konseling (BK) di SMA Negeri 2 Makassar mengatakan bahwa kasus-kasus bullying yang terjadi dilingkungan sekolah melibatkan siswa kelas $\mathrm{X}$ dan kelas maupun moral sehingga membuat remaja bingung dalam menempatkan dirinya di masyarakat. Hal ini sering membuat remaja mengungkapkan emosi negatifnya dengan cara yang tidak tepat, misalnya dengan melakukan perilaku bullying.

Gross dan John (2003) mengemukakan bahwa regulasi emosi merupakan kemampuan individu untuk menyadari dan mengatur pikiran dan perilakunya dalam emosi yang berbeda, baik emosi yang positif maupun emosi yang negatif. Cowie dan Jennifer (2008) mengemukakan bahwa salah satu faktor penyebab terjadinya kecenderungan perilaku bullying adalah regulasi emosi yang buruk atau sifat temperamen individu. Kemampuan individu dalam mengontrol emosi yang rendah menyebabkan gangguan perilaku, sehingga memilih melakukan perilaku bullying.

Santrock (2007) mengemukakan bahwa remaja dengan regulasi emosi yang rendah akan memicu masalah, sehingga rentan melakukakan perilaku bullying.
Remaja dikatakan telah mencapai kematangan emosinya apabila tidak meledakkan emosinya yang tidak pada tempatnya. Dari berbagai kasus bullying yang terjadi pada remaja dapat dilihat bahwa persoalan yang mendasar dikarenakan remaja kurang mampu mengendalikan emosi dalam dirinya. Bullying dapat merugikan bagi semua manusia apabila cara penyaluran emosi atau regulasi emosi individu tidak dapat dikendalikan dengan baik.

Berdasarkan uraian diatas, peneliti tertarik untuk melakukan penelitian regulasi emosi dengan bullying siswa kelas XII SMA Negeri 2 Makassar. Adapun hipotesis dalam penelitian ini yaitu:

1. Ada hubungan negatif antara regulasi emosi dengan bullying pada siswa kelas XII SMA Negeri 2 Makassar. Semakin tinggi regulasi emosi, maka semakin rendah perilaku bullying siswa kelas XII SMA Negeri 2 Makassar, begitupun sebaliknya.

2. Ada perbedaan perilaku bullying yang dilakukan siswa kelas XII SMA Negeri 2 Makassar berdasarkan jenis kelamin.

\section{METODE PENELITIAN}

Penelitian ini merupakan penelitian kuantitatif. Sugiyono 
mengemukakan bahwa skala merupakan teknik pengumpulan data dengan cara memberi seperangkat pertanyaan atau pernyataan secara tertulis kepada subjek untuk dijawab. Skala dalam penelitian ini menggunakan skala model Likert. Skala model Likert merupakan model skala yang menggunakan sistem rating untuk mengukur sikap, pendapat, dan persepsi individu mengenai fenomena sosial. Skala model Likert membagi item dalam dua jenis, yaitu favorable dan unfavorable.

Populasi dalam penelitian ini yaitu 402 siswa kelas XII di SMA Negeri 2 Makassar. Teknik sampel yang digunakan dalam penelitian simple random sampling. Simple random sampling merupakan teknik pengambilan sampel dari semua anggota populasi yang dilakukan secara acak apabila suatu populasi yang kondisinya relatif homogen. Dalam penelitian ini jumlah sampel ditentukan dengan menggunakan rumus yang dikembangkan oleh Isaac dan Michael (Sugiyono, 2013). Berdasarkan tabel Isaac dan Michael dengan tingkat kesalahan $5 \%$ jumlah sampel dalam penelitian ini sebanyak 191 siswa dari total populasi 420 siswa. Namun, dalam pengambilan data peneliti menambahkan sampel sebanyak 11 siswa. Sehingga, sampel dalam penelitian ini sebanyak 202 siswa.
Teknik pengumpulan data yang digunakan dalam penelitian ini yaitu:

1. Skala regulasi emosi diukur dengan menggunakan skala yang disusun berdasarkan aspek Thompson (1994) dengan jumlah 9 aitem. Hasil analisis daya diskriminasi aitem menunjukkan bahwa 19 aitem yang gugur dari 28 aitem yang telah diuji cobakan dengan koefisien korelasi total pada aitem yang tidak gugur dalam penelitian ini bergerak dari angka $\quad 0,306 \quad-0,668$. Koefisien reliabilitas skala regulasi emosi pada uji coba skala yang dilakukan dengan 28 aitem dan menggunakan 40 subjek, diperoleh nilai reliabilitas 0,801 .

2. Skala bullying diukur dengan menggunakan skala yang disusun berdasarkan aspek Cowie dan Jennifer (2008) dengan jumlah 24 aitem. Hasil analisis daya diskriminasi aitem menunjukkan bahwa 16 aitem yang gugur dari 40 aitem yang telah diuji cobakan dengan koefisien korelasi total pada aitem yang tidak gugur dalam penelitian ini bergerak dari angka 0,252 hingga 0,777. Koefisien reliabilitas skala bullying pada uji coba skala yang dilakukan dengan 40 aitem dan menggunakan 40 
subjek, diperoleh nilai reliabilitas 0,932 .

Hipotesis tersebut merupakan hipotesis yang menyatakan korelasi atau hubungan dan datanya berbentuk ordinal sehingga dianalisis menggunakan teknik statisik Spearman Rank Correlation. Selain itu, Nurgiyantoro, Gunawan, dan Marzuki (2009) mengemukakan bahwa uji t-test merupakan teknik pengujian yang digunakan untuk mengukur dua kelompok sampel yang berbeda. Penelitian ini menggunakan uji t-test untuk mengukur perbedaan perilaku bullying berdasarkan jenis kelamin subjek. Untuk mengetahui hipotesis dari penelitian ini di ukur dengan bantuan SPSS 24.0 for windows. Kriteria yang digunakan dalam uji hipotesis ini, yaitu:

1. Jika nilai signifikansi $\mathrm{p}>0,05$ maka Ha ditolak Ho diterima

2. Jika nilai signifikansi $\mathrm{p}<0,05$ maka Ha diterima Ho ditolak.

\section{HASIL DAN PEMBAHASAN}

Subjek dalam penelitian ini berjumlah 202 siswa laki-laki dan perempuan yang duduk dibangku kelas XII di SMA Negeri 2 Makassar. Gambaran subjek penelitian dapat dilihat dari Tabel 1 dan deskripsi data penelitian pada Tabel 2 sebagai berikut:

Tabel 1. Deskripsi subjek penelitian berdasarkan jenis kelamin

\begin{tabular}{lc}
\hline Jenis Kelamin & Jumlah \\
\hline Laki-laki & 67 \\
Perempuan & 135 \\
\hline Jumlah & $\mathbf{2 0 2}$ \\
\hline
\end{tabular}

Tabel 2. Deskripsi data penelitian

\begin{tabular}{lcccc}
\hline \multirow{2}{*}{ Variabel } & \multicolumn{4}{c}{ Hipotetik } \\
& Min & Max & Mean & SD \\
\hline Bullying & 24 & 96 & 60 & 12 \\
\hline Regulasi Emosi & 9 & 36 & 22,5 & 4,5 \\
\hline
\end{tabular}

Pertama, skala bullying berjumlah 24 item dengan rentang skor 1 sampai 4. Data hasil penelitian menunjukkan bahwa mean hipotetik bullying yaitu 60 dengan standar deviasi 12. Data hasil penelitian menunjukkan bahwa skor terendah adalah 24 dan untuk skor tertinggi adalah 96. Adapun kategori skor bullying dilihat pada tabel sebagai berikut: 
Tabel 3. Deskripsi Bullying

\begin{tabular}{cccc}
\hline Interval & Frekuensi & Persen & Kriteria \\
\hline $\mathbf{( 7 2 )} \leq \mathbf{X}$ & 1 & $0,49 \%$ & Tinggi \\
\hline $\mathbf{( 4 8 )} \leq \mathbf{X}<\mathbf{( 7 2 )}$ & 59 & $29,20 \%$ & Sedang \\
\hline $\mathbf{X}<(\mathbf{4 8 )}$ & 142 & $70,29 \%$ & Rendah \\
\hline Jumlah & $\mathbf{2 0 2}$ & $\mathbf{1 0 0 \%}$ & \\
\hline
\end{tabular}

Berdasarkan tabel di atas menunjukkan bahwa siswa kelas XII SMA Negeri 2 Makassar yang berada pada kategori perilaku bullying tinggi sebanyak 1 siswa dengan persentase $0,49 \%$, siswa yang berada pada kategori perilaku bullying sedang sebanyak 59 siswa dengan persentase $29,20 \%$, dan 70,29\% atau 142 siswa yang berada pada kategori perilaku bullying rendah. Jadi, hasil persentase menunjukkan bahwa siswa kelas XII di SMA Negeri 2 Makassar berada dalam kategori rendah dengan persentase 70,29\% atau sebanyak 142 siswa.

Sistem penanaman nilai-nilai pendidikan karakter kepada siswa di SMA Negeri 2 Makassar yang berhubungan dengan Tuhan Yang Maha Esa, diri sendiri, sesama siswa, dan lingkungan sekolah yang terwujud dalam pikiran, sikap, perasaan, perkataan dan perbuatan berdasarkan norma-norma agama yang berlaku. Penanaman nilai-nilai agama dalam SMA Negeri 2 Makassar baik, hal tersebut dikarenakan setiap waktu sholat siswa dipersilahkan untuk beribadah dan berdasarkan hasil observasi peneliti tampak bahwa disela-sela kesibukan siswa menjelang ujian sekolah dan nasional diberikan kegiatan tambahan yaitu dzikir bersama dilingkungan sekolah, sehingga proses tersebut mengurangi kecenderungan siswa dalam melakukan bullying.

Berdasarkan hasil wawancara yang dilakukan peneliti terhadap guru Bimbingan Konseling (BK) SMA Negeri 2 Makassar mengemukakan bahwa perilaku bullying saat ini sudah mulai berkurang dilingkungan sekolah, hal tersebut dikarenakan pihak sekolah telah memperketat aturan dan meningkatkan pengembangan karakter siswa melalui kegiatan ekstrakurikuler dan kegiatan keagamaan. Selain itu pihak sekolah memberikan sanksi tegas kepada siswa yang melakukan tindakan bullying dalam bentuk apapun. Untuk mengurangi tindakan bullying di lingkungan sekolah sering kali guru Bimbingan Konseling memberikan arahan kepada siswa untuk tidak melakukan hal tersebut

Skala regulasi emosi berjumlah 9 item dengan rentang skor 1 sampai 4. Data hasil penelitian menunjukkan bahwa mean 
hipotetik regulasi emosi adalah 22,5 dengan standar deviasi 4,5. Adapun kategori skor regulasi emosi dapat dilihat pada tabel 4 sebagai berikut:

Tabel 3. Deskripsi Regulasi Emosi

\begin{tabular}{cccc}
\hline Interval & Frekuensi & Persen & Kriteria \\
\hline $\mathbf{2 7}) \leq \mathbf{X}$ & 20 & $10 \%$ & Tinggi \\
\hline $\mathbf{( 1 8 )} \leq \mathbf{X}<(\mathbf{2 7})$ & 145 & $72 \%$ & Sedang \\
\hline $\mathbf{X}<(\mathbf{1 8})$ & 37 & $18 \%$ & Rendah \\
\hline Jumlah & $\mathbf{2 0 2}$ & $\mathbf{1 0 0 \%}$ & \\
\hline
\end{tabular}

Data hasil penelitian menunjukkan mean hipotetik regulasi emosi yaitu 22,5 dengan standar deviasi 4,5. Hasil penelitian menunjukkan pada kategori regulasi emosi tinggi sebanyak 20 subjek dengan persentase $10 \%$, siswa kelas XII SMA Negeri 2 Makassar yang berada pada kategori regulasi emosi sedang sebanyak 145 subjek dengan persentase $72 \%$, dan siswa yang berada pada kategori regulasi emosi rendah sebanyak 37 siswa dengan persentase $18,31 \%$. Sehingga, hasil persentase menunjukkan bahwa siswa kelas XII di SMA Negeri 2 Makassar masuk kedalam kategori regulasi emosi sedang.

Hasil ini menunjukkan bahwa siswa kelas XII di SMA Negeri 2 Makassar cukup mampu untuk mengatur emosi pada dirinya. Regulasi emosi berkaitan dengan kemampuan kognisi individu (Dewinda dan Efrizon, 2018). Responden dalam penelitian ini merupakan siswa kelas XII di
SMA Negeri 2 Makassar. Responden telah melalui berbagai macam aktivitas akademik selama bersekolah sehingga hal tersebut meningkatkan kemampuan kognitifnya, seperti kegiatan pembelajaran, ekstrakulikuler, dan relasi pertemanan. Proses tersebut dapat meningkatkan kemampuan siswa dalam beradaptasi di berbagai kondisi sehingga mampu meregulasi emosi dengan lebih baik.

Hipotesis dalam penelitian ini adalah ada hubungan negatif regulasi emosi dengan bullying pada siswa kelas XII SMA Negeri 2 Makassar. Artinya bahwa semakin tinggi regulasi emosi siswa kelas XII SMA Negeri 2 Makassar maka perilaku bullying yang dilakukan akan rendah, begitupun sebaliknya. Berdasarkan hasil uji hipotesis dengan menggunakan teknik Spearman Rank Correlation dengan bantuan program aplikasi SPSS 24.0 for windows dapat dilihat pada tabel 5 sebagai berikut: 
Tabel 5. Hasil uji hipotesis hubungan regulasi emosi dengan bullying pada siswa kelas XII SMA Negeri 2 Makassar

\begin{tabular}{lccc}
\hline \multicolumn{1}{c}{ Variable } & $\boldsymbol{R}$ & $\boldsymbol{P}$ & Keterangan \\
\hline $\begin{array}{l}\text { Regulasi Emosi } \\
\text { Bullying }\end{array}$ & $-0,230$ & 0,001 & Signifikan \\
\hline
\end{tabular}

Hasil uji hipotesis pada tabel 5 melakukan perilaku bullying. Individu menunjukkan nilai koefisien korelasi (r) antara regulasi emosi dengan bullying pada siswa kelas XII di SMA Negeri 2 Makassar yaitu sebesar -0,230 dengan nilai signifikan (p) sebesar 0,001. Kaidah hipotesis yang digunakan dalam penelitian ini adalah nilai signifikan yang ditunjukkan lebih kecil dari $0,05(\mathrm{p}<0,05)$, sehingga Ha diterima dan Ho ditolak. Dapat disimpulkan bahwa terdapat hubungan negatif yang signifikan antara regulasi emosi dengan bullying pada siswa kelas XII SMA Negeri 2 Makassar.

Cowie dan Jennifer (2008) mengemukakan bahwa salah satu faktor penyebab terjadinya kecenderungan perilaku bullying adalah regulasi emosi yang buruk atau sifat temperamen individu. Siswa yang memiliki sifat tempramen tinggi cenderung akan menjadi inividu yang lebih agresif. Remaja yang bingung dalam menempatklan dirinya di lingkungan sekolah karena mengalami berbagai macam perkembangan yang mencapai kematangan fisik, mental, sosial dan emosional, sehingga sering membuat remaja mengungkapkan emosi negatifnya dengan cara yang tidak tepat, misalnya dengan dengan kemampuan regulasi emosi yang baik dapat mengembangkan kemampuan dirinya dalam mengendalikan emosi yang sedang dialami.

Mawardah dan Adiyanti (2014) mengemukakan bahwa kemampuan individu dalam meregulasi emosi yang baik dapat membantu individu dalam mengontrol dirinya untuk tidak terlibat dalam perilaku negatif seperti bullying terutama ketika sedang mengalami masalah atau tekanan dari dalam dirinya maupun lingkungannya. Hal tersebut berarti kemampuan dalam meregulasi emosi berpengaruh terhadap kemampuan individu dalam mengontrol dirinya sehingga dapat membuat seseorang mengarahkan perilakunya dengan baik dan terhindar dari perilaku bullying. Hal ini sejalan dengan pendapat yang dikemukakan oleh Hamid (2016) Pada dasarnya pengalaman emosi yang dimaknai oleh individu dapat menjadi sumber motivasi maupun sumber stressor yang akan menentukan cara atau strategi untuk mengelola dengan baik emosi yang dirasakan agar mampu mengatasi atau 
menghadapi dengan baik situasi yang berlangsung.

Hasil dari penelitian ini sejalan dengan penelitian sebelumnya yang dilakukan oleh Puspitasari (2015) tentang hubungan regulasi emosi dengan bullying pada remaja mengemukakan bahwa hasil penelitian ini menunjukkan adanya hubungan negatif yang signifikan antara regulasi emosi dengan perilaku bullying remaja. Penelitian lain yang sama dilakukan oleh Dewinda dan Efrizon (2018) mengenai hubungan antara regulasi emosi dengan perilaku bullying pada santri kelas XII di Pondok Pesantren Terpadu Serambi Mekkah Padang Panjang. Hasil penelitian ini menyebutkan bahwa ada hubungan negatif antara variabel regulasi emosi dengan perilaku bullying, artinya semakin tinggi regulasi emosi maka semakin rendah perilaku bullying yang dimiliki santri kelas XII di Pondok Pesantren Terpadu Serambi Mekkah Padang Panjang begitupun sebaliknya.

Penelitian ini menggunakan uji hipotesis tambahan untuk mengetahui perbedaan perilaku bullying antara siswa laki-laki dan siswa perempuan kelas XII di SMA Negeri 2 Makassar berdasarkan jenis kelamin. Adapun hasil uji t-test dapat dilihat pada tabel 6 berikut:

Tabel 6. Deskripsi perbedaan perilaku bullying antara siswa laki- laki dan perempuan berdasarkan jenis kelamin

\begin{tabular}{lccc}
\hline \multicolumn{1}{c}{ Variable } & $\boldsymbol{T}$ & $\boldsymbol{P}$ & Keterangan \\
\hline $\begin{array}{l}\text { Laki-Laki } \\
\text { Perempuan }\end{array}$ & 6,644 & 0,000 & Signifikan \\
\hline
\end{tabular}

Berdasarkan hasil uji hipotesis tambahan pada tabel 6 menunjukkan bahwa nilai signifikansi (p) sebesar 0,000 dengan nilai (t) sebesar 6,644 sehingga, terdapat perbedaan yang signifikan antara perilaku bullying siswa laki-laki dan siswa perempuan kelas XII SMA Negeri 2 Makassar berdasarkan jenis kelamin. Kemudian, berdasarkan nilai mean siswa laki-laki menunjukkan nilai sebesar 49,4 dan nilai mean siswa perempuan sebesar 38,5, hal tersebut menunjukkan bahwa terdapat perbedaan perilaku bullying siswa laki-laki dengan siswa perempuan yang duduk di bangku kelas XII di SMA Negeri 2 Makassar berdasarkan nilai mean.

Dagun (Finiswati dan Matulessy, 2018) mengemukakan bahwa terdapat perbedaan secara rinci laki-laki dan perempuan. Laki-laki memiliki karakteristik sangat agresif, tidak emosional, dominan, sangat aktif, sangat kompetitif, terbuka, dapat mengambil keputusan dengan cepat, percaya diri, 
menyukai tantangan, menyukai situasi agresif, ambisius dan sedikit membutuhkan keamanan. Sedangkan, perempuan Tidak agresif, emosional, tidak senang kompetitif, pasif, tertutup, sulit membuat keputusan dengan mudah, tidak percaya diri, tidak menyukai situasi agresif, tidak berambisi, dan sangat membutuhkan keamanan.

Berdasarkan penelitian yang dilakukan Hermalinda, Deswita, dan Oktariana (2017) diperoleh hasil bahwa siswa laki-laki lebih tinggi melakukan perilaku bullying dengan bentuk bullying fisik, verbal, dan sosial dibandingkan dengan siswa perempuan. Dalam penelitian ini siswa perempuan lebih sedikit terlibat dalam kasus-kasus bullying. Penelitian yang sama dilakukan oleh Finiswati dan Matulessy (2018) tentang kecenderungan melakukan bullying ditinjau dari jenis kelamin dan urutan kelahiran pada santri di Pondok Pesantren diperoleh hasil bahwa terdapat perbedaan perilaku bullying berdasarkan jenis kelamin. Artinya bawah individu yang berjenis kelamin lakilaki cenderung mempunyai perilaku bullying yang lebih tinggi daripada perempuan.

\section{PENUTUP}

Berdasarkan hasil dan analisis dan permbahasan dalam penelitian ini, menunjukkan bahwa:

1. Ada hubungan negatif antara regulasi emosi dengan bullying pada siswa kelas XII di SMA Negeri 2 Makassar. Makin tinggi regulasi emosi siswa, maka makin rendah perilaku bullying, begitupula sebaliknya.

2. Terdapat perbedaan yang signifikan perilaku bullying yang dilakukan oleh siswa laki-laki dengan perempuan. Siswa laki-laki lebih tinggi melakukan bullying dibandingkan siswa perempuan.

\section{DAFTAR PUSTAKA}

Cowie, H., \& Jennifer, D. (2008). New perspectives on bullying. New York: McGraw-Hill Education.

Dewinda, H. R., \& Efrizon. (2018). Hubungan antara regulasi emosi dengan perilaku bullying pada santri kelas XII di Pondok Pesantren Terpadu Serambi Mekah Padang Panjang. UPI YPTK Jurnal Psyche, 11(1), 37- 44.

Gross, J. J., \& John, O. P. (2003). Individual differences in two emotion regulation processed: Implications for affect, relationships, and well being. Journal of Personality and Social Psychology, 85(2), 348-362.

Finiswati, E., \& MAtulessy, A. (2018). Kecenderungan melakukan bullying ditinjau dari jenis kelamin dan urutan kelahiran pada santri di Pondok Pesantren. Jurnal Psikologi. 1(1), 1323.

Hamid, A. N. (2016). Makna Kompetensi Emosi Bagi Manager Dalam Pengambilan Keputusan. Jurnal Publikasi Pendidikan, VI (2), 130140. 
Hermalinda., Deswita., \& Oktariana, E. (2017). Hubungan karakteristik remaja dengan perilaku bullying pada siswa SMP di Kota Padang. Jurnal Keperawatan Soediman, 12(1), 1-11.

Indrawan, A. F. (2017). KPAI Terima Aduan 26 Ribu Kasus Bully Selama 2011-2017. Diakses pada tanggal 7 Desember 2018. https://news.detik.com.

Istianah, U. (2018). 3 kasus bullying mengerikan di indonesia, satu di pinrang Diakses pada 14 November 2018. https://makassar.terkini.id

Mawardah, M., \& Adiyanti, MG. (2014). Regulasi emosi dan kelompok teman sebaya pelaku cyberbullying. Jurnal Psikologi, 41(1), 60-73.

Nicolaides, S., Toda, Y., \& Smith, P. K. (2002). Knowledge and attitudes about school bullying in trainee teachers. British Journal of Educational Psychology, 72, 105118.

Nurgiyantoro, B., Gunawan., Marzuki. (2009). Statistik terapan: Untuk penelitian ilmu- ilmu sosial. Yogyakarta: Gadjah Mada University Press.

Puspitasari, I. F. (2015). Hubungan antara regulasi emosi dengan kecenderungan perilaku bullying pada remaja. (Skripsi diterbitkan). Surakarta: Universitas Muhammadiyah Surakarta.

Santrock, J. W. (2002). Perkembangan masa hidup edisi ke-13. Terjemahan oleh Achmad Chusaini \& Juda Damanik. Jakarta: Erlangga.

Santrock, J. W. (2007). Remaja edisi 11 jilid 1. Terjemahan oleh Benedictine Widysinta. Jakarta: Erlangga. 